ISSN 2078-6441. Вісник Львівського університету. Серія географічна. 2013. Випуск 44. С. 372-378. Visnyk of the Lviv University. Series Geography. 2013. Issue 44. P. 372-378.

502.72:546.16

\author{
лентин ригуб \\ деський н ціон льний університет імені ллі ечников , \\ вул. ворянськ, 2, 65057, м. дес , кр їн
}

фтором і його сполук ми пов'яз ні і др м тичн історія відкриття, і под льше його використ ння у всіх сфер х життя: від томної енергетики і р кетно-космічної техніки до медицини одноч с фтор спричиняє з непокоєння щодо свого нег тивного впливу н орг нізми рослин, тв рин і людей. ро н лізов но т хронологічно уз г льнено дослідження фтору в н вколишньому середовищі. исвітлено внесок окремих учених стосовно історії відкриття т досліджень фтору. изн чено основні н прями суч сних досліджень мікроелемент .

лючові слов : фтор, історія досліджень, н вколишне середовище.

суч сних умов х фтор є однією із н йбільш поширених з бруднюв льних речовин у повітрі, грунті, природних вод х, продукт х х рчув ння. ін т кож н лежить до ктивних тмосферних і водних мігр нтів. імія фтору вирізняється специфічністю, що виявляється, головно, у винятково високій ре кційній зд тності мікроелемент т у своєрідності вл стивостей фторовмісних сполук. тор ре гує м йже зі всім елемент ми, крім гелію, неону й ргону [6].

ерез високу ре кційну зд тність фтор не існує в природі у вільному ст ні, його одержують електролізом розпл влених солей. ільний фтор скл д ється з двох томних молекул іє м йже безб рвним г зом, що м є різкий др тівний з п х, який одноч сно н г дує 3 п х хлору й озону. же в невеликих концентр ціях він ур ж є дих льні шляхи і м є сильну з г льнотоксичну дію. ожливо, тому історія його відкриття бул скл дною і небезпечною.

б'єктом н шого дослідження є фтор у системі природне середовище-людин , предметом - історичні спекти відкриття т дослідження фтору в природних компонент $\mathrm{x}$.

$m$ мет - історико-геогр фічний н ліз досліджень фтору. ля досягнення мети пост влено т кі з вд ння: ) про н лізув ти ступінь вивченості проблеми; б) висвітлити внесок окремих учених у відкриття т геогр фічні дослідження фтору, в) дослідити н прям суч сних геогр фічних і медико-геогр фічних досліджень фтору.

ля вирішення пост влених з вд нь використ но літер турні джерел щодо історії відкриття т досліджень фтору, т кож вл сні дослідження шодо вмісту фтору в природних компонент х (у тому числі в тмосферних оп д х, грунт х, природних вод х, рослин х) івнічно- хідного ричорномор'я.

полуки фтору, які тр пляються в природі, очевидно, були відомі і їх використовув ли досить д вно. жко ск з ти, хто і коли вперше поч в з стосовув ти мінер ли фтору н пр ктиці. мовірніше, це були д вні мет лурги і лхіміки. ерші зг дки про флюор і флюорит стосуються XV ст. і пов'яз ні з мінер лом флюоритом (пл виковим шп том). е з д вніх ч сів було відомо: якщо флюорит дод ти під ч с випл влення

(C) ригуб ., 2013 
мет лу до руди, то темпер тур пл влення руди і шл ків знижується, що зн чно полегшує проведення процесу (звідси н зв мінер лу від л т. fluo - течу) [3].

трим ння сполук фтору, яких нем є в природі, ст ло вже 3 вд нням хіміків.

1771 р. шведський хімік рл ільгельм ееле, обробивши флюорит сірч ною кислотою, приготув в кислоту, яку він н зв в “пл виковою”. р нцузький учений нту н ву зьє припустив, що до скл ду цієї кислоти входить новий хімічний елемент, який він з пропонув в н зв ти “флуорем”. роте виділити новий елемент вони не змогли. об підтвердити припущення вчених і виділити фтор, хімік м різних кр їн зн добилося пон д 100 років.

хожість між хлористо- і фтористоводневою кислот ми свідчило про існув ння фтору, хімічно н дзвич йно ктивного елемент, що н лежить до групи г логенів. всі спроби виділити вільний фтор з розпл влених солей фтористих сполук з зн в ли невд чі, оскільки 3 високої темпер тури, як для цього бул потрібн , вивільнений фтор ре гув в з водою, з посудиною, де відбув л ся ре кція, з електрод ми. исок токсичність сполук фтору серйозно шкодил здоров’ю дослідників. г то учених, які н м г лися отрим ти фтор у вільному ст ні, 3 гинули під ч с проведення т ких дослідів бо ст ли інв лід ми. е i нглійські хіміки бр ти ом с і еорг окс, які спробув ли отрим ти фтор із фторидів срібл і свинцю, і фр нцузи .- . ей- юсс к . . ен р т б г то інших, досліди яких з кінчилися тр гічно. мфрі еві, першим отрим вши н трій, к лій, к льцій т інші елементи, ун слідок експериментів 3 отрим ння фтору електролізом отруївся і в жко з хворів. мовірно, під вр женням усіх цих невд ч 1816 р. для нового елемент було з пропонов но хоч й схожу з звуч нням, проте з бсолютно іншим сенсом н зву - фтор (від гр. phtoros - руйнув ння, 3 гибель). ьогодні ця н зв елемент прийнят тільки в російській мові, фр нцузи і німці н зив ють фтор fluor, нглійці - fluorine [6]. трим ти фтор у вільному вигляді не зміг і т кий вид тний учений, як $\mathrm{p}$ дей.

ільки 1886 р. фр нцузький хімік нрі у сс н зумів виділити вільний фтор, використовуючи як електроліт безводний фторид к лію, розчинений у безводній фтористоводневій кислоті, і пл тино-іридієві електроди. ерез технічні труднощі, пов'яз ні 3 отрим нням фтору з високих темпер тур, . у усс н досліджув в хімічні вл стивості фторсполук 3 дуже низьких темпер тур. зом 3 шотл ндським хіміком жеймсом ью ром він отрим в рідкий фтор $3-23^{\circ}$, який н віть 3 цієї темпер тури ре гув в 3 воднем і вуглевод ми. ізніше . у сс н т к пис в про цей період: “ тор з бр в у мене 10 років життя”. лектроліз досі є пр ктично єдиним методом отрим ння вільного фтору.

поч тку ХX ст. фтор і н д лі використовув ли обмежено - у вигляді флюориту головно під ч с випл влення мет лу.

оч тком н ступного періоду досліджень фтору можн вв ж ти кінець 30-х років, i пов'яз ний він з бурхливим розвитком ст лелив рної, хімічної й оборонної промисловості. імеччині, , нглії розпоч лися дослідження 3 синтезув ння фосфорорг нічних токсичних речовин. оксичність цих речовин зумовлен зд тністю пригнічув ти діяльність життєво в жливого ферменту - холінестер зи. і сполуки зд тні виклик ти судино-п р літичну і міотичну дію [4].

ч си ругої світової війни вл стивості елемент використ ли для виробництв зброї м сового знищення, у тому числі й томної зброї. прикл д, трифторид фтору використовув ли як підп люв льний з сіб; деякі фторовмісні сполуки в мериці, еликій рит нії і імеччині розгляд ли як секретні отруйні речовини. допомогою 
летких фторидів ур ну (шестифтористий ур н) вд лося домогтися розділення $\mathrm{p}$ діо ктивних ст більних ізотопів ур ну і вирішити проблему отрим ння ядерного п лив .

ерші дослідження вмісту фтору в земній корі н ведені в пр цях вид тних геохіміків . ерн дського (1913), . иногр дов (1937), . ольдшмідт (1938), ерсм н (1933) [5].

ослідження з визн чення фтору в природних вод х розпоч лися ще н прикінці 30-х років ( . иногр дов, 1937; . ойсеєв, 1937; . ельм нов 1937; . нилов , 1940; . в'ялов, 1940; . гєєв , 1942). роте їх виконув ли в невеликих м сшт б х, вони були регіон льними й висвітлюв ли вміст фтор-іон лише в деяких водних джерел $\mathrm{x}$ вропейської ч стини

йзн чніші результ ти досліджень фтору стосуються другої половини XX ст. цей період зн чну ув гу як у дянському оюзі, т к і в інших кр їн х світу приділяли вивченню поширення фтору в природному середовищі в зв'язку з ендемічними з хворюв ннями н селення (н к рієс і флюороз). огляду н це проводили дослідження фтору в грунт х, поверхневих і підземних вод х, експеримент льні дослідження з розчинності фторовмісних мінер лів, передусім фосфоритів, які вносилися в грунти з мінер льними добрив ми. ей н прям розвинуто в пр цях . бович $(1957,1969)$, . еркинського, сл вської (1953), . тр ус (1953), . р йнов , . етров $(1976,1978)$, . озлов $(1969,1972)$, . ом ров $(1965,1981)$ т інших дослідників. ивч ючи мінер льний скл д підземних вод, . бович т . p йнов (1972) уперше звернули ув гу н зв'язок між вмістом у вод х к льцію, м гнію і фтору [5].

дним із н йдет льніше досліджених регіонів бул територія суч сної кр їни. егіон льні дослідження провели . отелянськ (1959 р., к рп тськ обл.), . урецьк (1956 р., ьвівськ обл.), . йструк (1963 р., інницьк обл.), митроченко (1966 р., в но- р нківськ обл.), . вловий (1962 p., ерсонськ обл.), · пко (1960 р., ентр льн зон кр їни), . идоренко (1960 р., онецьк обл.), . ЙКо (1966 р., рим), . овг н (1963 р., олт вськ обл.).

. ерн дський, вивч ючи особливості колообігу фтору в біосфері, дійшов висновку, що фтор н явний в усіх компонент х біосфери і є яскр вим прикл дом розсіяного ст ну елементів. чений ув ж в, що основне джерело фтору в біосфері - гірські породи. рім того, деяк кількість фтору потр пляє в біосферу з терм льними вод ми і вулк нічними г з ми. міст фтору в грунт х визн чений його концентр цією в м теринських пород х, що ж стосується особливостей його розподілу в грунтовому профілі, то вони з леж ть від грунтотворних процесів, із яких н йв жливіше зн чення м ють інтенсивність звітрюв ння і вміст глинистих ч сток [1].

визн ченням б г тьох дослідників, середній вміст фтору в грунт х земної кулі оцінюють у 320 мг/кг. йнижчі концентр ції елемент виявлено в піщ них грунт х гумідних р йонів, н йвищі - у в жких глинистих грунт х і в грунт х, які утворилися н основних пород $\mathrm{x}$.

д ними . иногр дов (1958), вміст фтору в грунт х уської рівнини в ріює в меж х 30-320 мг/кг. грунт х ді п зон вмісту ще ширший: від слідів до 7070 мг/кг грунту. ля більшості грунтів вміст фтору змінюється в меж х 150-400 мг/кг, хоч верхні межі концентр ції відрізняються зн чним ді п зоном колив нь. окрем, у деяких в жких грунт х у р йон х колишнього бо суч сного вулк нізму, де відбув ється розсіюв ння фтор п титу, вміст фтору перевищує 1000 мг/кг. ідвищений вміст фтору в грунт х, б г тих н к рбон ти [8]. 
ні окремих вторів, звич йно, не охоплюють усієї різном нітності концентр ції фтору в грунт х кр їн. дн к інформ ція, отрим н 3 декільком бо н віть одним x p ктерним для кр їни грунтом, м є зн чний інтерес i, безсумнівно, деякою мірою відобр ж є геохімію фтору в грунт х конкретного регіону.

міст водорозчинного фтору в грунт х світу, і зокрем уської рівнини, т кож в ріює в широких меж х: сліди - 68 мг/кг. роте кількість експеримент льних д них стосовно водорозчинного фтору незн чн порівняно з фтором в ловим. ільшість досліджень (. інер, . трижов (1973); . трижов , . існиченко (1975); . єліченко (1975); . ігм тул єв, . ілонєц (1975); . люк, . укоб усов (1992); . оголєв, . ригуб (1992); . ригуб (2001, 2002, 2003, 2008)) м ють регіон льний х р ктер. . єліченко, . ігм тул єв , . ілонєц досліджув ли вміст водорозчинного фтору в грунт х з хст ну; . інер, . трижов , . існиченко, . рейдм н-у грунт х олдови, . ригуб - у чорноземних грунт х івнічно- хідного ричорномор'я [8].

тор зн чно поширений у рослинних і тв ринних орг нізм х, його вміст у них 3 лежить від вмісту в зовнішньому середовищі. перше н явність фтору в рослин х визн чив . юллер ще 1845 p., і лише 1913 p. . отьє і . л усм н провели дет льніші дослідження і зн йшли фтор у 64 досліджув них вид х рослин, причому відмінності вмісту між вид ми були зн чними. прикл д, щ вель, листя буряку, п пороті містили фтору, відповідно, 139, 134 і 85 мг/кг сухої речовини, боби, моркв , бульби к ртоплі - 2,1, 3,6 і 30 мг/кг. ередній вміст фтору в різних орг н х рослин колив ється від 0,1-5,0 мг/кг сухої речовини. дн к у б г тьох вип дк х він може зменшув тися м йже до нуля бо збільшув тися до кількох сотень мілігр мів [2, 4]. д ними . бович, у продукт х х рчув ння рослинного походження різних $\mathrm{p}$ йонів кр їни кількість фтору колив ється від 0,01 до 0,77 мг/кг сирої речовини. йб г тшими н фтор є зернові продукти $(0,2-0,7$ мг/кг). . рилов зн йшл в овоч х фтору від 0,1 до 1-3 мг н 1 кг сухої речовини. йбільшу кількість фтору виявлено в листк х петрушки (32 мг/кг), н йменшу - в моркві, буряку, к пусті й цибулі (відповідно, 0,025, 0,030, 0,039, 0,038 мг/кг сухої речовини).

г льної думки дослідників стосовно з лежності вмісту фтору в рослин х від його вмісту в грунт х дотепер не вироблено. - иногр дов, н прикл д, ув ж є: якщо т ке зб г чення відбув ється, то воно незн чне. ксперименти . бович пок з ли, що вміст фтору в рослин х у р зі внесення в грунт суперфосф ту $200 \mathrm{Kг} / \Gamma$, підвищується незн чно. вип дку внесення в грунт 1000 кг/г суперфосф ту вміст фтору в рослин х різко зрост є [4]. ільшість дослідників ув ж $є$, що вміст фтору в рослин х не 3 лежить від його вмісту в грунт х. чевидно, цей висновок не $є$ дост тньо обгрунтов ним, оскільки 3 зн чені втори користуються результ т ми визн чення в грунт х фтору, м лодоступного рослин м. о ж стосується визн чення вмісту рухомих форм, зокрем, водорозчинних, то це пит ння дотепер м ловивчене. н шими дослідженнями, вміст ктивного фтору в соці рослин прямо з лежить від його вмісту в грунт х. ричому в рослин х фтор н копичується в зн чно більших кількостях, ніж у грунт $\mathrm{x}$.

ромисловими джерел ми фтору є головно з води 3 випл влення люмінію i виробництв фосф тних добрив. т лелив рні, цегельні й скляні 3 води, т кож сп люв ння вугілля - дод ткові джерел з бруднення н вколишнього середовищ фтором. рім того, високий вміст фтору в грунт х пов'яз ний з використ нням 
фосф тних добрив, стічних вод і пестицидів. огляду н високий вміст фтору в фосф тних добрив х н дходження його в орні грунти м є суттєве екологічне зн чення.

ро інтенсивне н копичення фтору в грунт х у р зі трив лого з стосув ння мінер льних добрив свідч ть численні д ні вегет ційних і ст ціон рних польових дослідів ( . удзін, . шов (1978); . плін (1994); . нделов (1997); . оголєв, . ригуб (1992); . ригуб (1999, 2008); . емєндяєв т ін. (1992); . ремленков (1993); . удзін (1970) т ін.).

тже, фосфорні добрив, будучи могутнім з собом підвищення врож ю сільськогоспод рських культур, водноч с $є$ джерелом з бруднення грунтів, грунтових вод і продуктів х рчув ння фтором.

промислових стоків н йбільше з бруднюють фтором гідросферу відходи виробництв гірничорудного (видобуток бокситів, флюориту), мет лургійного, хімічного, н фтопереробного, деревообробного, гутного, л коф рбового виробництв [4].

ормув ння лок льних техногенних ном лій фтору в грунт х т інших природних об'єкт х пов'яз не з тмосферними викид ми підприємств з виробництв люмінію, фосфорних добрив, кольорових і чорних мет лів, скл, будівельних м тері лів тощо (. ремленков (1993); . оловков , . иволобов (1992); . женін т ін. (1987); . p їв (1993); . олов, . менщиков (1985); . оз новск я, . оршин (1986); . 6 т - енди с, . енди с (1989); . оцик т ін. (1990); . ригуб $(1998,2008))$.

ивчення вмісту фтору в різних тк нин х т орг н х людини є необхідною л нкою у спр ві з'ясув ння біологічної ролі мікроелемент . изн ч ючи вміст фтору в тк нин х людського орг нізму, дослідники ігнорув ли концентр цію мікроелемент в н вколишньому середовищі, що не д в ло змоги достовірно оцінюв ти отрим ні результ ти, i, відповідно, ускл днюв ло виявлення з кономірностей.

тв ринних тк нин х фтор уперше виявив оріхіні 1803 р. в зуб х викопних слонів. другої половини XIX ст. проведено низку досліджень, які пок з ли, що фтор є постійною скл довою ч стиною не тільки твердих, й м'яких тк нин людського орг нізму. ч сом у літер турі поч ли н копичув тися вельми суперечливі д ні щодо вмісту фтору в кістк х (від 100 до 9700$)$, зуб х (від 90 до 16000 мг/кг), крові (від 0,01 до 2,0 мг/кг) т інших тк нин х. дослідженнями . бович, н йбільш кількість фтору міститься у твердих опорних тк нин х, менше - у волоссі, нігтях, тобто у тк нин х з м лоінтенсивним мет болізмом, порівняно стійких і міцних. внутрішніх орг н х, з лоз х, мозку, де процеси обміну інтенсивні, кількість фтору зменшується. инятк ми є ендокринні з лози. йменш кількість фтору міститься у м'яз х $\mathrm{i}$ мозковій тк нині.

кінця 50-х років ст. не припиняється робот н д вивченням впливу фтору н здоров'я людини. исленні публік ції вид тного укр їнського гігієніст, к демік

бович $\mathrm{T}$ його учнів і послідовників створили підгрунтя для успішного вирішення теоретичних і пр ктичних спектів кондиціонув ння питних вод 3 вмістом фтору, прогнозув ння дин міки т геогр фічної поширеності ендемічного флюорозу т к рієсу зубів тощо.

дослідженнями різних вторів ( . иногр дов , . воронков , . діков , бович , . вруцького, . інгер , . ойн р , . укомського, . оломійцевої, 6 т - енді с, . енді с, . ейко, . вцин , . йфуліної, . ерпен к, ляхов , . осенко, . еньг ) н длишок фтору в питній воді і х рчових продукт х спричиняє руйнув ння зубної ем лі, пригнічує вуглеводний, фосфорно-к льцієвий обмін, ктивність деяких ферментів. ін є специфічним інгібітором утворення гексозо- 
дифосфорної т молочної кислот, бере уч сть у згорт нні крові, регулюв нні функцій шитоподібної з лози. к інгібітор б г тьох ферментів, фтор може г льмув ти внутрішньоклітинні процеси синтезу, які посл блюють імуноз хисні сили орг нізму і можуть прискорюв ти процеси фізіологічного ст ріння.

уч сні дослідження, головно, пов'яз ні з вивченням еколого-медичних спектів вмісту фтору в системі н вколишнє середовище-людин . прикл д, основні з кономірності розподілу фтору в об’єкт х довкілля, умови його мігр ції й інтегр ції, т кож 3 г льні пит ння геохімії фтору т ендемічного з хворюв ння розглянуто в пр цях овинського (1969-2002). роблемі впливу фтору у вод х і х рчових продукт х н здоров'я н селення присвячені пр ці . оворознюк (1997), . нх нен (1998), · ижевського, · рупник, · оменк , · ононович (1997-2001), . род нчук, . удрого т ін. (2008). изн чення з кономірностей розподілу і мігр ції фтору т його форм зн ходження у підземних вод $\mathrm{x}$, які з стосовують для водопост ч ння н території кр їни, розглянуто . рюченко (2002). котоксилогічн оцінк небезпечності фтору з лежно від грунтово-клім тичних умов т з стосув ння мінер льних добрив н веден в пр ці . іщук (2004). оль водного ф ктору у формув нні стом тологічного здоров'я н селення розглянуто в пр цях . осенко (2011), . еньг , сипк т ін. (2010).

одноч с є б г то пит нь, які потребують спеці льних досліджень н суч сному piвні. е стосується проблеми визн чення з кономірностей мігр ції фтору т його форм у природних вод х з суч сних природних і техногенних умов. собливу ув гу приверт є т кож низк пит нь щодо виявлення осередків ендемічних 3 хворюв нь і прогнозув ння територій екологічного ризику. скільки фтор є в дуже вузькому ді п зоні концентр цій, то необхідне проведення фторидного моніторингу.

тже, сьогодні фториди широко використовують у хімічній і ст лелив рній промисловості, медицині, рослинництві й тв ринництві. н ними пов'язують перспективу лікув ння злоякісних пухлин, регулюв ння сп дковості, створення сильних психотропних з собів, тр нквіліз торів і нових нтибіотиків. вдяки кту льності, в жливому господ рському зн ченню т б г тогр нності проблем фтору переросл прив тні пит ння окремої г лузі н уки, перетворившись у з г льнобіологічну й екологічну.

езв ж ючи н зн чну кількість досліджень з вивчення впливу фтору н здоров'я н селення, не всі дослідники дійшли однозн чних висновків щодо його мінім льного т оптим льного вмісту в різних компонент х природного середовищ . кий ст н проблеми можн пояснити тим, що нем комплексного вивчення вмісту фтору в н вколишньому середовищі т його впливу н здоров'я н селення.

оцільним є проведення систем тичного фторидного моніторингу в природних компонент х для з побіг ння з хворюв ності н селення, в тому числі й н стом тологічні хвороби.

\section{СПИСОК ВИКОРИСТАНОЇ ЛІТЕРАТУРИ}

1. иногр дов . . еохимия редких и р ссеянных химических элементов в почв х / . . иногр дов. - . : , 1957. -237 с.

2. иногр дов . . икроэлементы в жизни р стений и животных / . . иногр дов. - . : ук , 1952. -80 с. 
3. редные химические веществ . еорг нические соединения V-VIII групп : пр в. изд. / [ . . ндм н, . . олков , . . рехов и др.]. - . . имия, 1989. - 592 с.

4. бович . . тор и его гигиеническое зн чение / . . бович. - . : едгиз, 1957. $-251 \mathrm{c}$.

5. овинский . . еохимия фтор (прикл дное зн чение) / . . овинский, . . ур ев .- иев : ук. думк , 1987. - 160 с.

6. сик в . оединения фтор / [ . сик в , . бэ, . г сэ и др.]. - . : ир, 1990. $-407 \mathrm{c}$.

7. $6 m-е н д и$. икроэлементы в почв х и р стениях / . 6 т - енди с, . енди с / [пер. с нгл.]. - . : ир, 1989. - . 306-316.

8. ригуб . . тор у чорнозем х південного з ходу кр їни : [ оногр фія] / . . ригуб, . . озняк. - ьвів : ид вничий центр імені в н р нк, 2008. -148 c.

\author{
m ття:н дійшл до ред кції 11.04.2013 \\ доопр цьов н 15.05 .2013 \\ прийнят до друку 17.06.2013
}

\title{
HISTORY OF RESEARCH OF FLUORINE
}

\section{Valentina Trigub}

Ilya Mechnikov National University of Odesa, Dvorianska St., 2, UA - 65057, Odesa, Ukraine

Drama histories of opening of fluorine and in the subsequent its use in all spheres of a life (from atomic engineering and the space-rocket technics to medicine) are connected with fluorine and its compound. Simultaneously fluorine causes anxiety consuming the negative influence on organisms of plants, animals and people. Chronologically researches of fluorine in the environment were analyzed and summarized in the article. There is shown the contribution of certain scholars in the history of the discovery and study of fluorine. The main directions of current research of the microelement are determined.

Key words: fluorine, history of research, environment.

\author{
лентин ригуб \\ десский н цион льный университет имени льи ечников, \\ ул. ворянск я, 2, 65057, г. десс, кр ин
}

фтором и его соединениями связ ны и др м тическ я история открытия, и в последующем его использов ние во всех сфер х жизни: от томной энергетики и р кетно-космической техники до медицины. дновременно фтор вызыв ет оп сения в отношении своего нег тивного влияния н орг низм р стений, животных и людей. ро н лизиров но и хронологически обобщено исследов ния фтор в компонент х окруж ющей среды. тобр жено вкл д отдельных ученых к с емо истории открытия и исследов ний фтор . пределено основные н пр вления современных исследов ний микроэлемент .

лючевые слов : фтор, история исследов ний, окруж ющ я сред . 